\title{
Development of single-locus DNA microsatellite markers using 50anchored ISSR-PCR method for the mangrove horseshoe crab, Carcinoscorpius rotundicauda (Latreille, 1802) in Peninsular Malaysia
}

\begin{abstract}
Horseshoe crabs are said to be declining worldwide. However, there is still no published report on the status of horseshoe crabs in Malaysia. Thus, we report here eight informative microsatellite markers that were developed using the 50-anchored ISSR-PCR enrichment procedure to diagnose the population genetic structure of the mangrove horseshoe crab, Carcinoscorpius rotundicauda from Peninsular Malaysia. This set of markers was tested on 127 samples and showed polymorphism in this species. Hence they should be useful in future essential population genetic studies of these living fossils in the Southeast Asian region.
\end{abstract}

Keyword: Mangrove horseshoe crab; C. rotundicauda; 5' anchored ISSR-PCR; Microsatellite. 